January 2017

\title{
Family planning practices of rural community dwellers in cross River State, Nigeria.
}

\author{
A. J. Etokidem \\ University of Calabar, Nigeria \\ W. Ndifon \\ University of Calabar, Nigeria \\ Ekaete Asuquo \\ Aga Khan University, ekaete.asuquo@aku.edu \\ J.Etowa \\ University of Ottawa
}

Follow this and additional works at: https://ecommons.aku.edu/eastafrica_fhs_sonam

Part of the Nursing Commons

\section{Recommended Citation}

Etokidem, A. J., Ndifon, W., Asuquo, E., Etowa, J. (2017). Family planning practices of rural community dwellers in cross River State, Nigeria.. Nigerian Journal of Clinical Practice, 20(6), 707-715.

Available at: https://ecommons.aku.edu/eastafrica_fhs_sonam/216 


\title{
Original Article
}

\section{Family Planning Practices of Rural Community Dwellers in Cross River State, Nigeria}

\author{
AJ Etokidem, W Ndifon, $J$ Etowa ${ }^{1}, E F$ Asuquo $^{2}$
}

Departments of Community Medicine and ${ }^{2}$ Nursing, University of Calabar, Calabar, Nigeria, ${ }^{1}$ School of Nursing, University of Ottawa, Ottawa, Canada

Date of Acceptance: 28-Oct-2016

\section{INTRODUCTION}

$\mathcal{W}$ ith a population of approximately 170 million, Nigeria is the most populous nation in Africa and the seventh most populous in the world. ${ }^{[1]}$ Both the annual population growth rate of $3.2 \%$ and a total fertility rate of 5.5 per woman rank among the highest in the world. ${ }^{[2,3]}$ Nigerian women have approximately one more child than they would want. ${ }^{[2]}$ With this, the total fertility rate is $15 \%$ higher than what it would be if all unwanted births were avoided. ${ }^{[2]}$

\begin{tabular}{|l|l|}
\hline \multicolumn{2}{|c|}{ Access this article online } \\
\hline Quick Response Code: & Website: www.njcponline.com \\
\cline { 2 - 2 } & DOI: 10.4103/njcp.njcp_193_15 \\
\cline { 2 - 2 }
\end{tabular}

The 2013 NDHS indicated that the median age at first birth among women aged 25-49 years was 20.2 years; among women who had a live birth in the 3 years preceding the survey, the median duration of insusceptibility to pregnancy was 12.6 months. ${ }^{[2]}$ An

Address for correspondence: Dr. Aniekan Jumno Etokidem, Department of Community Medicine, Faculty of Medicine and Dentistry, University of Calabar, Calabar, Nigeria. E-mail: etokidem@etokidem.com

This is an open access article distributed under the terms of the Creative Commons Attribution-Non Commercial-Share Alike 3.0 License, which allows others to remix, tweak, and build upon the work non-commercially, as long as the author is credited and the new creations are licensed under the identical terms.

For reprints contact: reprints@medknow.com

How to cite this article: Etokidem AJ, Ndifon W, Etowa J, Asuquo EF. Family planning practices of rural community dwellers in cross River State, Nigeria. Niger J Clin Pract 2017;20:707-15. 
earlier study recorded a differential in mean age at first birth among rural dwellers in south-western Nigeria (20.8 \pm 3.7 years) and urban dwellers $(23.2 \pm 5.1$ years $)$. ${ }^{[4]}$ Another study also found that $26.9 \%$ of girls in Ogaja and Obudu Local Government Areas of Cross River State of Nigeria had already given birth before their 20th birthday. ${ }^{[5]}$ Comparatively, the Ghana Demographic and Health Survey, 2008 showed that the median age at first birth for all women aged 25-49 years was 20.7 years. ${ }^{[6]}$ In the United States of America, the mean age at first birth is reported to be 25.8 years. ${ }^{[7]}$

Contraceptive prevalence in Nigeria is one of the lowest in the world. The NDHS 2008 recorded a prevalence of $13 \%$, and the 2013 NDHS recorded a marginal rise to $15 \% .^{[2]}$ The NDHS 2013 reports that, although $85 \%$ of Nigerian women and $95 \%$ of Nigerian men report having knowledge of a contraceptive method, only $15 \%$ of currently married women use a contraceptive method, with an unmet need for family planning of $16 \%$ among married women. ${ }^{[2]}$ A related research in Ilorin, Nigeria found that, although all 600 respondents were aware of contraceptives, only $25.4 \%$ had used one form of contraceptive method or another. ${ }^{[8]}$ This was lower than the $52.5 \%$ respondents who had used one form of contraception or another in Uyo, Nigeria. ${ }^{\left[{ }^{[]}\right.}$The observed difference may be attributed to the fact that the Uyo study utilized hospital clients, (ANC attendees) whereas the Ilorin study was conducted among students. In a study on family planning behaviors and decision-making among couples in Cross River State, Nigeria, it was found that spousal communication and male involvement in family planning increases the likelihood of fertility control. ${ }^{[10]} \mathrm{A}$ similar study found that $61.3 \%$ of respondents in a rural community in Cross River State were currently using one form of family planning method or another. ${ }^{[1]}$ The Cross River State Government's Strategic Health Development Plan (2010-2015) indicates that the contraceptive prevalence in the state is $16 \%{ }^{[12]}$

One of the key determinants of contraceptive use in Nigeria is female education. ${ }^{[13]}$ In a study in Osun State, Nigeria, it was found that respondents' educational status, occupation of the partner, communication with the spouse regarding contraceptive use, and approval of a contraceptive method were significant determinants of use of at least one modern contraceptive method. ${ }^{[14]}$ Educated women were more likely to understand and appreciate why they should have fewer children for whom they can provide better education than women who were uneducated. The education of the spouse was also likely to increase the probability of contraceptive use by a woman. ${ }^{[14]}$
In a related study from rural Kenya, it was found that a rural woman's level of education was inversely associated with her level of unmet need for family planning. ${ }^{[15]}$ In another study in rural Ghana, it was found that perception of partner acceptability was a strong predictor of intention to use postpartum family planning $(\mathrm{OR}=3.20 ; 1.94-5.48) .{ }^{[16]}$

Rural women are known to show reluctance towards utilization of modern methods of family planning. ${ }^{[17]} \mathrm{A}$ study in rural western Kenya found that rural women had low perception regarding modern family planning services offered by Community Health Workers. ${ }^{[18]}$ Modern family planning methods include female and male sterilization, oral hormonal pills, intrauterine device (IUD), male condom, female condom, injectables, implant (including Norplant), vaginal barrier methods, emergency contraception, standard days method, basal body temperature method, two-day method, lactational amenorrhea method, and symto-thermal method. ${ }^{[19]}$ Traditional methods of family planning are the calendar method (rhythm method) and withdrawal (coitus interruptus). ${ }^{[19]}$ The fear of both primary and secondary infertility has been documented as one of the causes of reluctance towards the use of modern family planning methods. ${ }^{[20,21]}$ The World Health Organization (WHO) defines primary infertility as the inability of a woman to ever bear a child either due to the inability to become pregnant or the inability to carry a pregnancy to a live birth. ${ }^{[22]}$ Secondary infertility is defined as the inability to become pregnant or the inability to carry a pregnancy to a live birth following either a previous pregnancy or a previous ability to carry a pregnancy to a live birth. ${ }^{[22]}$

It has been documented that the total fertility rate in some Nigerian rural communities is higher than that in urban communities (6.2 versus 4.7$)$, a situation that has been made worse by low contraceptive prevalence in rural communities. ${ }^{[2]}$ This study, therefore, seeks to determine the family planning practices of rural community dwellers in Cross River State of Nigeria with a view to inform relevant interventions.

\section{Study objectives}

1. To determine the knowledge of family planning among rural community dwellers in Cross River State of Nigeria.

2. To determine the contraceptive prevalence among the respondents.

3. To identify family planning preferences of the respondents.

4. To identify determinants of family planning practice among the respondents. 


\section{Materials and Methods}

\section{Study area}

This study was conducted in Cross River State of Nigeria. Cross River State is one of the states in Nigeria's oil rich Niger Delta Region. The region is characterized by both urban and rural poverty, with a low literacy rate. Cross River State shares a common boundary with the Republic of Cameroon in the east, Benue State in the north, Abia and Ebonyi States in the west, and Akwa Ibom State and the Atlantic Ocean in the south. The population of the state is over 3 million. There are three major ethnic groups in the state namely Efik, Ejagham, and Bekwara. The state has a total of 18 Local Government Areas (LGAs) grouped into three senatorial districts. Most of the rural areas are agrarian, requiring enough hands to help in farming which is not mechanized. There are traditional beliefs, cultural practices, myths, and misconceptions that act as barriers to the utilization of maternal, newborn, and child health services, including family planning services.

\section{Sample size determination, sampling technique,} and data collection method

The minimum sample size was determined using the Leshlie-Kish formula:

$n=\mathrm{z}^{2} \mathrm{pq} / \mathrm{d}^{2}$

where $n$ is the minimum sample size, $\mathrm{z}$ is the standard normal deviate, which at the $95 \%$ significance level is set at 1.96, and $\mathrm{p}$ is the prevalence of the desired characteristic.

A study in Ilorin, Nigeria found that $25.4 \%$ of respondents had used one form of contraceptive method or another. ${ }^{[8]}$ Therefore $\mathrm{p}$ was set at 0.254 .

$\mathrm{q}=1-\mathrm{p}$

$\mathrm{d}=$ degree of accuracy, which is set here at 0.05 .

Thus, $n=291$

This study was conducted among rural women in the three senatorial districts of Cross River State, Nigeria. Convenience sampling method was used. The inclusion criteria were being from one of the rural LGAs in the state and giving an informed consent. The women were assembled in a hall and a questionnaire was administered to every rural woman who gave informed consent until the sample size was attained. The questionnaire contained both open-ended and close-ended questions (semi-structured). The questionnaires were issued to the respondents to complete on their own (selfadministered). The variables in the questionnaire included sociodemographic variables such as age, sex, marital status, occupation, religion, educational status, and ethnic grouping. Other variables included use of at least one family planning method at some point in time and current use of any family planning method, who makes the decision regarding family planning practice, and types of family planning methods known to the respondents.

\section{Data analysis}

Out of the 291 questionnaires administered, 290 were correctly completed while one was not and therefore discarded. Data obtained from the study were analyzed using the Statistical Package for the Social Sciences version 20 (IBM Corporation). The results were presented in tables as frequencies and percentages and figures. Association between categorical variables was explored using chi-square test. Binary logistic regression was also performed to determine predictors of use of at least one family planning method.

\section{Ethical consideration}

The data for this study were collected in keeping with the declaration of Helsinki. Informed consent was obtained from all the respondents.

\section{Results}

\section{Sociodemographic variables}

Table 1 and Figure 1 show the sociodemographic characteristics. Sixty-eight (23.4\%) respondents were aged 45 years and above, while those in the 15-19 age group were the least $6(2.1 \%)$. Two hundred and eightyone $(96.9 \%)$ of the respondents were Christians while $3(1.0 \%)$ belonged to other religions. There were more farmers, $64(22 \%)$ than retirees, 34 (11.7\%). Majority of the respondents, $209(72.1 \%)$ were married while 48 $(16.8 \%)$ were single. One hundred and twenty-seven $(43.8 \%)$ respondents had tertiary education while 61 (21\%) had primary education. There was no respondent without a formal education. The Efiks constituted 20.7\% of respondents, $24.8 \%$ were of the Ejagham tribe, $25.2 \%$ were of Bekwara origin, and other tribes constituted $1 \%$ of the study population.

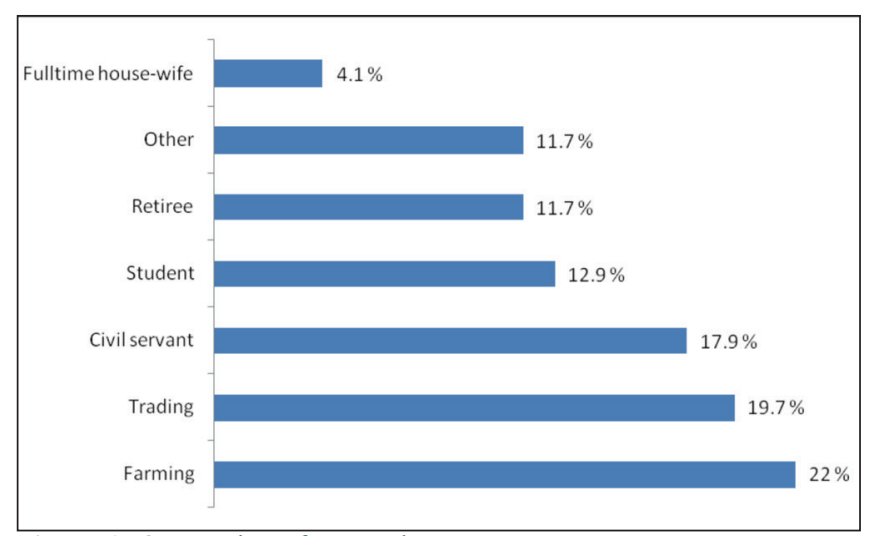

Figure 1: Occupation of respondents 


\section{Knowledge of family planning}

Majority of the respondents, 236 (78.9\%) obtained information about family planning from health care providers, $122(40.8 \%)$ from television, $107(35.8 \%)$ from newspapers, $159(53.2 \%)$ from radio, while 86 $(28.7 \%)$ obtained it from training workshops [Figure 2]. One hundred and thirty-two (44.1\%) indicated that family planning was "limitation of the number of children one should have," $156(52.2 \%)$ indicated that it is "spacing and timing of child birth," 101 (33.8\%) indicated that it is "prevention of unwanted pregnancies," $37(12.4 \%)$ indicated that it is "prevention of sexually transmitted diseases," $134(44.8 \%)$ indicated that it is "birth control," while 76 (25.4\%) indicated that it is "a means of assisting families to anticipate and attain the desired number of children" [Table 2].

Majority of the respondents, 285 (98\%) indicated that family planning services could be accessed at health care facilities while $6.9 \%$ indicated "chemist" and 10.3\% indicated "pharmacy." Secondary infertility was the side effect of family planning methods indicated by 245 $(84.5 \%)$ respondents, followed by irregular menstruation indicated by 215 (74.1\%) respondents. Weight loss was

\begin{tabular}{|c|c|c|}
\hline \multicolumn{3}{|c|}{$\begin{array}{l}\text { Table 1: Sociodemographic characteristics of } \\
\text { respondents }\end{array}$} \\
\hline Variable & Frequency & Percentage \\
\hline \multicolumn{3}{|c|}{ Age group (in years) } \\
\hline $15-19$ & 6 & 2.1 \\
\hline $20-24$ & 27 & 9.3 \\
\hline $25-29$ & 54 & 18.6 \\
\hline $30-34$ & 38 & 13.1 \\
\hline $35-39$ & 61 & 21.0 \\
\hline $40-44$ & 36 & 12.5 \\
\hline 45 and above & 68 & 23.4 \\
\hline Total & 290 & $100 \%$ \\
\hline \multicolumn{3}{|l|}{ Religion } \\
\hline Christianity & 281 & 96.9 \\
\hline Islam & 6 & 2.1 \\
\hline Other & 3 & 1.0 \\
\hline Total & 290 & 100 \\
\hline \multicolumn{3}{|l|}{ Marital status } \\
\hline Single & 48 & 16.6 \\
\hline Married & 209 & 72.0 \\
\hline Separated & 4 & 1.4 \\
\hline Widowed & 29 & 10.0 \\
\hline Total & 290 & 100 \\
\hline \multicolumn{3}{|l|}{ Educational Status } \\
\hline Primary & 61 & 21.0 \\
\hline Junior Secondary & 23 & 7.9 \\
\hline Senior Secondary & 60 & 20.7 \\
\hline Tertiary & 127 & 43.8 \\
\hline Other & 19 & 6.6 \\
\hline Total & 290 & 100 \\
\hline
\end{tabular}

the least indicated side effect by 34 (11.7\%) respondents [Figure 3].

\section{Use of family planning methods}

One hundred and ninety-eight (68.3\%) respondents had used at least one family planning method at some point in time while $92(31.7 \%)$ had not. Only $50(17.2 \%)$ respondents were currently using at least one family planning method while $240(82.2 \%)$ were not. Fifty-four percent of those who were currently practicing family planning were using modern methods while $46 \%$ were using traditional methods. Forty-four percent of those currently on family planning had used it for less than 1 year while $20 \%$ had been on family planning for $1-5$ years, $24 \%$ for $6-10$ years, and $12 \%$ for more than 10 years [Table 3].

Concerning who makes decisions regarding the use of family planning method, $16.2 \%$ of the respondents indicated the wife as the decision-maker, $13.1 \%$ indicated the husband as the decision-maker, $66.6 \%$ indicated that the decision

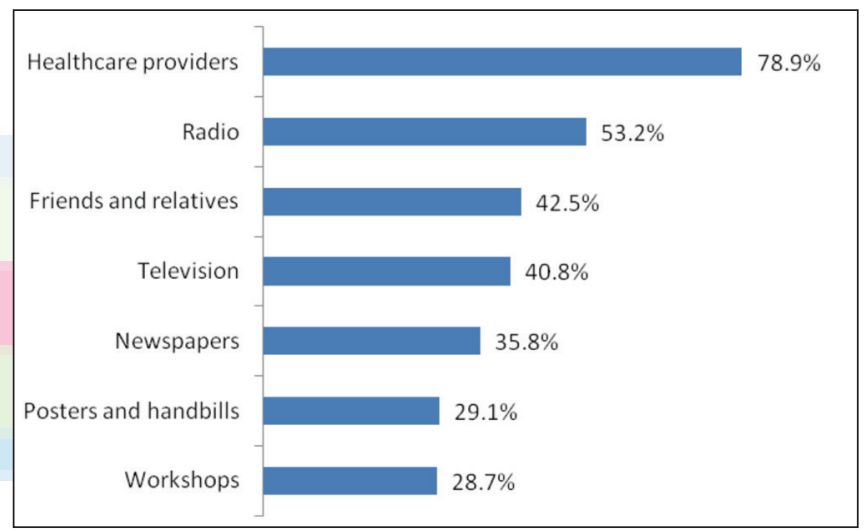

Figure 2: Sources of information regarding family planning

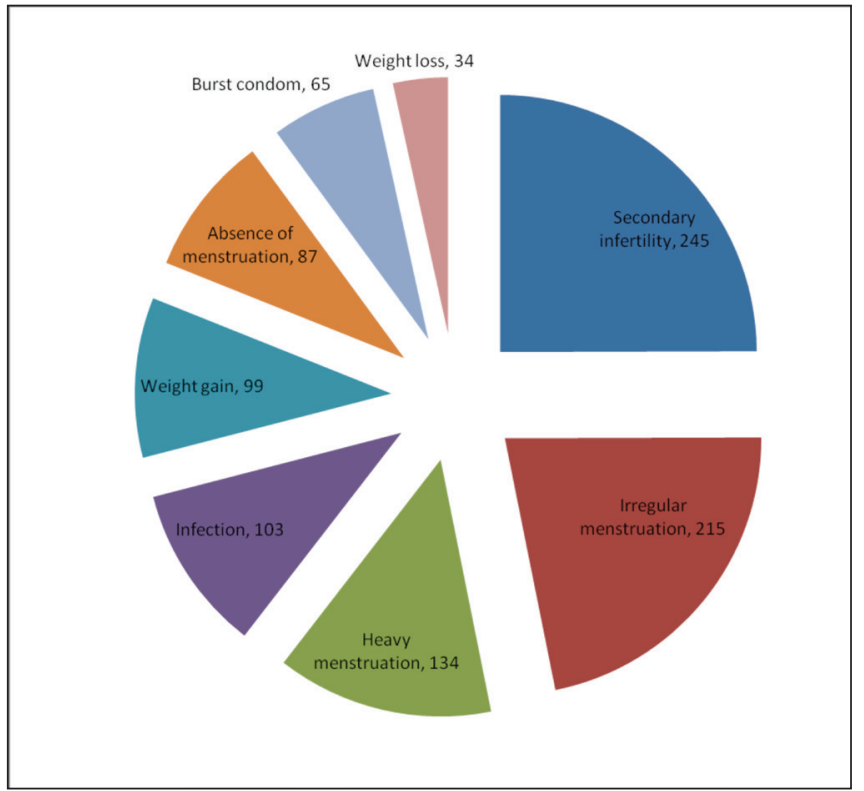

Figure 3: Knowledge of side effects of family planning 


\begin{tabular}{|c|c|c|}
\hline Variable & 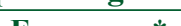 & \\
\hline \multicolumn{3}{|l|}{ Knowledge of definition of family planning } \\
\hline Limitation of the number of children one should have & 132 & 44.1 \\
\hline Spacing and timing of child birth & 156 & 52.2 \\
\hline Prevention of unwanted pregnancies & 101 & 33.8 \\
\hline Prevention of sexually transmitted diseases & 37 & 12.4 \\
\hline Birth control & 134 & 44.8 \\
\hline A means of assisting families to anticipate and attain the desired number of children & 76 & 25.4 \\
\hline \multicolumn{3}{|l|}{ Knowledge of where to obtain family planning services in the locality } \\
\hline Health facility (Hospital/Health center/clinic) & 285 & 98 \\
\hline Chemist & 20 & 6.9 \\
\hline Pharmacy & 30 & 10.3 \\
\hline Nongovernmental organization (NGO) & 15 & 5.2 \\
\hline Others & 13 & 4.5 \\
\hline
\end{tabular}

*Frequencies add up to $>290$ and percentages add up to $>100 \%$ because multiple responses were allowed.

\begin{tabular}{|c|c|c|}
\hline \multicolumn{3}{|c|}{ Table 3: Use of family planning method } \\
\hline Variable & Frequency & Percentage \\
\hline \multicolumn{3}{|c|}{ Have you ever used any family planning method? } \\
\hline Yes & 198 & 68.3 \\
\hline No & 92 & 31.7 \\
\hline \multicolumn{3}{|c|}{ Are you currently using any family planning method? } \\
\hline Yes & 50 & 17.2 \\
\hline No & 240 & 82.8 \\
\hline \multicolumn{3}{|c|}{ Family planning method in current use } \\
\hline Traditional method & 23 & 46 \\
\hline Modern method & 27 & 54 \\
\hline \multicolumn{3}{|c|}{ Length of use of family planning method } \\
\hline Less than one year & 22 & 44 \\
\hline One to five years & 10 & 20 \\
\hline Six to ten years & 12 & 24 \\
\hline More than ten years & 6 & 12 \\
\hline \multicolumn{3}{|c|}{ Who makes decision regarding family planning? } \\
\hline Wife & 47 & 16.2 \\
\hline Husband & 38 & 13.1 \\
\hline Both of us & 193 & 66.6 \\
\hline Others & 12 & 4.1 \\
\hline \multicolumn{3}{|c|}{ Reasons for choice of family planning method } \\
\hline If it is cheap & 39 & 13.0 \\
\hline Can be found easily & 29 & 9.7 \\
\hline Does not have side effects & 91 & 30.4 \\
\hline $\begin{array}{l}\text { Has little side effects compared to } \\
\text { others }\end{array}$ & 32 & 10.7 \\
\hline Very effective & 76 & 25.4 \\
\hline \multicolumn{3}{|c|}{ Would you recommend family planning to others? } \\
\hline Yes & 252 & 86.9 \\
\hline No & 38 & 13.1 \\
\hline
\end{tabular}

was made jointly by the wife and the husband, and $4.1 \%$ indicated that the decision was made by others [Table 3].

Reasons for not using any family planning method The following reasons were given for not using any family planning method: "family planning is against my

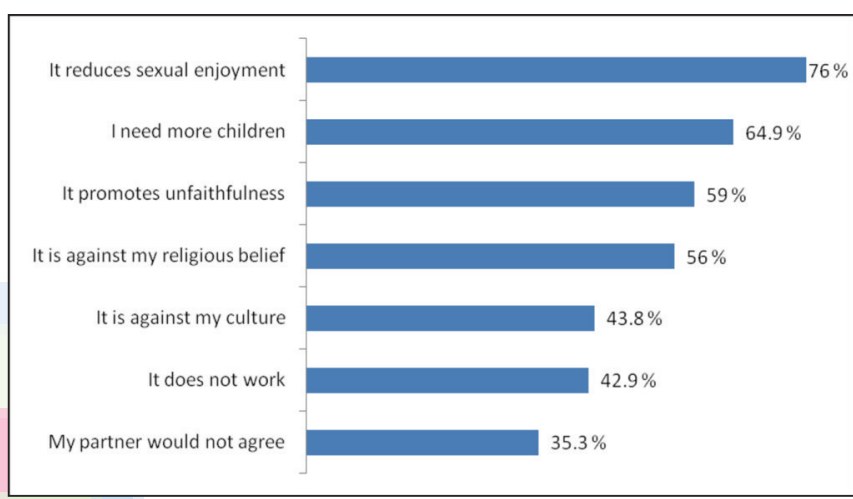

Figure 4: Reasons for not using any family planning method

religious belief" $56 \%$; "it is against my culture" $43.8 \%$; "I need more children" 64.9\%; "my partner would not agree" 33\%; "it does not work" $42.9 \%$; "it reduces sexual enjoyment" $76 \%$; and "it promotes unfaithfulness (infidelity)" 59\% [Figure 4].

\section{Test of association between variables}

Test of association showed that there was a statistically significant association between age group and current use of at least one family planning method $(P=0.007)$ and between occupation and current use of at least one family planning method $(P=0.002)$. There was no statistically significant association between religion, marital status, educational status, and tribe and current use of at least one family planning method. There was a statistically significant association between age group and use of at least one family planning method at some point in time $(P=0.000)$, religion and use of at least one family planning method at some point in time $(P$ $=0.025)$, occupation and use of at least one family planning method at some point in time $(P=0.026)$ and tribe, and use of at least one family planning method at some point in time $(P=0.037)$ [Table 4] and [Table 5]. 
Etokidem, et al:: Family planning practices of rural dwellers

\begin{tabular}{|c|c|c|c|c|c|c|}
\hline \multirow[t]{2}{*}{ Sociodemographic variable } & \multicolumn{2}{|c|}{ Current use of family planning } & \multirow{2}{*}{ Total (\%) } & \multirow{2}{*}{ Chi-Square } & \multirow{2}{*}{ df } & \multirow{2}{*}{ P-value } \\
\hline & Yes & No & & & & \\
\hline \multicolumn{7}{|l|}{ Age group (in years) } \\
\hline $15-19$ & $1(16.7)$ & $5(83.3)$ & $6(100)$ & & & \\
\hline $20-24$ & $3(11.1)$ & $24(88.9)$ & $27(100)$ & & & \\
\hline $25-29$ & $9(16.7)$ & $45(83.3)$ & $54(100)$ & & & \\
\hline $30-34$ & $8(21.1)$ & $30(78.9)$ & $38(100)$ & Fisher's & & \\
\hline $35-39$ & $17(27.9)$ & $44(71.1)$ & $61(100)$ & Exact & 6 & 0.007 \\
\hline $40-44$ & $9(25.0)$ & $27(75.0)$ & $36(100)$ & Test & & \\
\hline 45 and above & $3(4.4)$ & $65(95.6)$ & $68(100)$ & 16.812 & & \\
\hline Total & $50(17.2)$ & $240(82.8)$ & $290(100)$ & & & \\
\hline \multicolumn{7}{|l|}{ RELIGION } \\
\hline Christianity & $48(17.1)$ & $233(82.9)$ & $281(100)$ & Fisher's & & \\
\hline Islam & $2(33.3)$ & $4(6.7)$ & $6(100)$ & Exact & & \\
\hline Other & $0(0)$ & $3(100)$ & $3(100)$ & Test & 2 & 0.449 \\
\hline Total & $50(17.2)$ & $240(82.8)$ & $290(100)$ & 1.591 & & \\
\hline \multicolumn{7}{|l|}{ OCCUPATION } \\
\hline Farming & $6(9.8)$ & $55(90.2)$ & $61(100)$ & & & \\
\hline Trading & $20(35.1)$ & $37(64.9)$ & $57(100)$ & & & \\
\hline Civil Service & $8(15.4)$ & $44(84.6)$ & $52(100)$ & & & \\
\hline Student & $4(10.8)$ & $33(89.2)$ & $47(100)$ & 23.108 & 7 & 0.002 \\
\hline Full time House Wife & $0(0)$ & $12(100)$ & $12(100)$ & & & \\
\hline Retiree & $3(8.8)$ & $31(91.2)$ & $34(100)$ & & & \\
\hline Other & $9(26.5)$ & $25(73.3)$ & $34(100)$ & & & \\
\hline Total & $50(17.2)$ & $240(82.8)$ & $290(100)$ & & & \\
\hline \multicolumn{7}{|l|}{ MARITAL STATUS } \\
\hline Single & $6(12.5)$ & $42(87.5)$ & $48(100)$ & Fisher's & & \\
\hline Married & $40(19.1)$ & $169(80.9)$ & $209(100)$ & Exact & & \\
\hline Separated & $2(50)$ & $2(50)$ & $4(100)$ & Test & & \\
\hline Widowed & $2(6.9)$ & $27(93.1)$ & $29(100)$ & 6.085 & 3 & 0.089 \\
\hline Total & $50(17.2 \mathrm{w})$ & $240(82.8)$ & $290(100)$ & & & \\
\hline
\end{tabular}

Statistical significance was set at $P<0.05$

\section{Binary logistic regression}

Binary logistic regression [Table 6] conducted to predict use of at least one family planning method at some point in time using some independent variables showed that who makes the decision regarding family planning use was the strongest predictor of family planning use $(\mathrm{OR}=0.567 ; 95 \% \mathrm{CI}=0.391-0.821)$. This suggests that family planning uptake is more likely when couples make a joint decision regarding it. On the other hand, binary logistic regression of current use of family planning method as the dependent variable and the same independent variables showed that none of the independent variables was a predictor of current family planning use.

\section{DisCuSSION}

The finding of this study that majority of the respondents, $72.1 \%$, were married is similar to that of a study in Ogaja and Obudu LGAs in Cross River State of Nigeria, which found that $68.4 \%$ of respondents were married. ${ }^{[5]}$ However, the proportion of "separated" respondents in this study, $1.4 \%$, is lower than the $7.6 \%$ in the study in Ogoja and Obudu. The proportion of respondents with secondary school education that were currently using at least one family planning method was found to be $54.8 \%$ in this study. This is comparable with the $56.1 \%$ found in the Ogoja and Obudu study. ${ }^{[5]}$

The most common occupation of the respondents was farming $(22 \%)$. This is contrary to the findings of a related study in south-western Nigeria where the most common occupation of respondents was trading $(42.3 \%) .{ }^{[23]}$ The high proportion of farmers in this study is not unexpected because the respondents were from agrarian rural communities where subsistence farming is the main means of livelihood.

This study found that $17.2 \%$ of the respondents were currently using at least one family planning method. This is comparable to the $15 \%$ found by the NDHS 2013. ${ }^{[2]}$ The finding is also comparable to that of the Cross River State Government's Strategic Health Development 
Etokidem, et al:: Family planning practices of rural dwellers

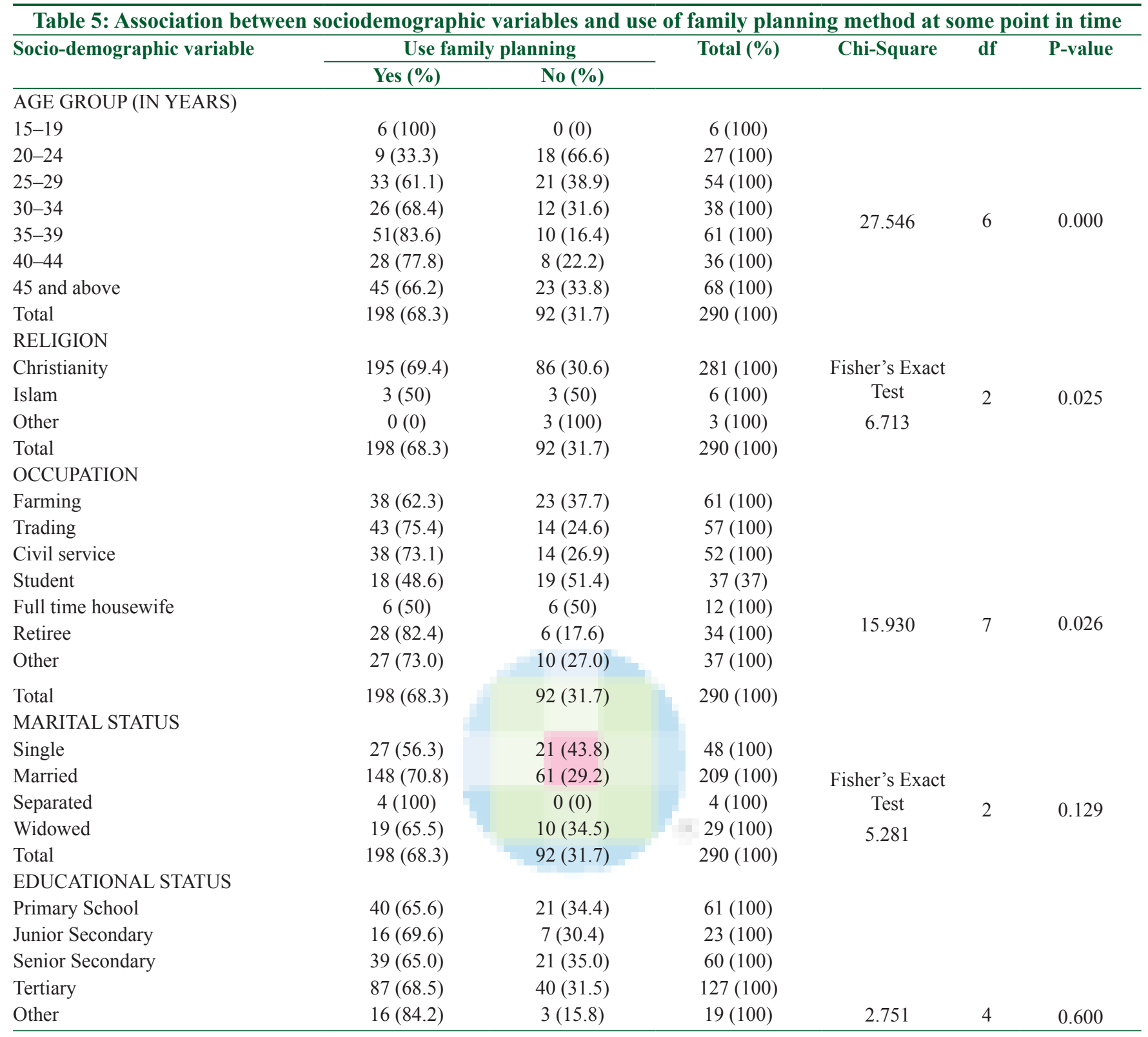

Table 6: Binary logistic regression of use of family planning method as dependent variable with some independent variables

\begin{tabular}{lcccccccc}
\hline & B & SE & Wald & df & Sig. & Exp(B) & \multicolumn{2}{c}{ 95\% CI for Exp(B) } \\
\cline { 7 - 9 } & & & & & & & Lower & Upper \\
\hline Age group & .166 & .089 & 3.520 & 1 & .061 & 1.181 & .993 & 1.406 \\
Religion & -.989 & .615 & 2.587 & 1 & .108 & .372 & .112 & 1.241 \\
Occupation & .016 & .067 & .058 & 1 & .810 & 1.016 & .891 & 1.159 \\
Marital status & .101 & .149 & .463 & 1 & .496 & 1.107 & .826 & 1.482 \\
Educational status & .233 & .122 & 3.675 & 1 & .055 & 1.263 & .995 & 1.603 \\
Tribal group & .073 & .041 & 3.203 & 1 & .074 & 1.075 & .993 & 1.165 \\
Decision maker & -.567 & .189 & 9.001 & 1 & .003 & .567 & .391 & .821 \\
Constant & .837 & 1.249 & .449 & 1 & .503 & 2.309 & & \\
\hline
\end{tabular}

Plan (2010-2015), which indicates that the contraceptive prevalence in the state is $16 \% \cdot{ }^{[12]}$ However, the finding of this study and that of the NDHS 2013 and the Cross River State Government's Strategic Health Plan are 
lower than the $66.3 \%$ of rural women in south-west Nigeria who were reported to be currently using one form of contraception or another. ${ }^{[23]}$

This study also found that $68.3 \%$ of the respondents had used at least one family planning method at some point in time. This is comparable to that of an earlier facilitybased study in Obudu in Cross River State of Nigeria, which found that $72 \%$ of the respondents had used one form of family planning method at one time or another. ${ }^{[24]}$ On the contrary, both figures are high compared to the $53 \%$ found among rural women in Nsukka in Enugu State of Nigeria. ${ }^{[25]}$ The proportion is, however, low compared to that of another study in Kano, Nigeria where $88.6 \%$ of respondents indicated that they had used contraceptives. ${ }^{[26]}$

Majority of respondents (78.9\%) obtained information about family planning from health care providers, whereas in a similar study among adolescents in Akwa Ibom State of Nigeria, it was found that this source accounted for $24.75 \%$ only. ${ }^{[27]}$ The study among adolescents reported that the main source of information among respondents was the radio (33.25\%) compared to $53.2 \%$ found in this study. The study among adolescents utilized a much younger population who may be busy obtaining information and news alerts from their telephone handsets than listening to the radio compared to the relatively older population in this study. In another related study in Uyo, Akwa Ibom State of Nigeria, it was found that doctors were the main source of family planning information for $36.9 \%$ of the respondents. ${ }^{[9]}$ This proportion is low compared to the $78.9 \%$ of respondents who obtained family planning information from healthcare providers in this study.

Binary logistic regression showed that the likelihood of using family planning methods increased when the decision was made jointly by both the husband and wife compared to when it was made by either party alone or by a third party. An earlier study found that husband's opposition was responsible for non-use of family planning among $24.2 \%$ of the respondents. ${ }^{[24]}$ This is similar to the $35 \%$ of respondents in this study who indicated that they did not use any family planning method because "my partner would not agree." Most Nigerian societies are patriarchal in nature and men have the dominant voice in most household matters, including health matters. Women are often not able to negotiate use of family planning services with their partners, as documented in another study ${ }^{[28]}$ Corroborating this is the observation of other studies that poor spousal communication regarding family planning can influence utilization. ${ }^{[29,30]}$ The findings of this study also justify recent advocacy for male involvement in family planning. ${ }^{[31,32]}$
It is encouraging that $86.9 \%$ of the respondents would recommend family planning to other women. However, significant harm can be done to family planning advocacy by the remaining $13.1 \%$ who indicated that they would not recommend it to others. There is a need for greater advocacy to win this (remaining) minority to the side of the majority.

This study found that $59 \%$ of respondents would not use any family planning method because family planning "promotes unfaithfulness." This proportion is higher than that found in an earlier study in south-west Nigeria, where $30.4 \%$ gave the same reason for not embracing family planning. ${ }^{[16]}$ Such fears should be addressed by using appropriate behavior change communication and helping people understand that there is no research evidence that practicing family planning encourages promiscuity.

Non-acceptance of family planning as a result of cultural beliefs, as indicated by $43.8 \%$ of the respondents, can be addressed by consistent health education and advocacy with messages that debunk myths and misconceptions associated with family planning. For those who would not embrace family planning because they perceive that it does not work, community members for whom it has worked could be identified and used as role models and change agents within their communities.

An appreciable proportion of respondents (64.9\%) would not embrace family planning because they want to have more children. This is not unexpected because these rural communities are mainly agrarian and more hands would be needed to help in farming, which is basically non-mechanized. The predominant occupation of the respondents is farming $(22.0 \%)$. Diversification of the means of livelihood through improved education and alternative employment opportunities for the people could be a means of addressing this reason for not using contraceptive methods.

\section{Conclusion}

The proportion of respondents who were currently using family planning was low. The findings of this study suggest that family planning uptake would increase if couples make joint decision in this regard. Although a good proportion of respondents have a positive attitude towards family planning and indicate their willingness to recommend it to others, there is a need to ensure a change of behavior and attitude of the remaining minority whose poor attitude could influence utilization of family planning services by others.

\section{Financial support and sponsorship}

Nil. 


\section{Conflict of Interest}

There are no conflicts of interest.

\section{REFERENCES}

1. PRB. 2012 World Population Data SheetPopulation Reference Bureau. Available from: http://www.prb.org/pdf12/2012population-data-sheet_eng.pdf. [Last accessed on 2015 July 12.]

2. National Population Commission (NPC) [Nigeria] and ICF International. 2014 Nigeria Demographic and Health Survey 2013. Abuja, Nigeria, and Rockville, Maryland, USA: NPC and ICF International; 2013.

3. Adebimpe WO, Asekun-Olarinmoye E, Bamidele JO, Abodunrin O. A comparative study of socio-demographic determinants and fertility pattern among women in rural and urban communities in Southwestern Nigeria. Continental J Med Res 2011;5:32-40.

4. Central Intelligence Agency (CIA). The World Fact Book: Total Fertility rate. Available from: https://www.cia.gov/library/ publications/the-world-factbook/fields/2127.html. [Last cited on 2016 Oct 01].

5. Ugal DB, Ushie BA. Contraceptive use among women in Ogoja and Obudu Local Government Areas, Cross River State, Nigeria. Afr Pop Stud 2013;2:155-63.

6. Ghana Statistical Service (GSS), Ghana Health Service (GHS) and ICF Macro2009. Ghana Demographic and Health Survey 2008. Accra, GhanaGSS, GHS, and ICF Macro.

7. CDC: Births and Natality; June 12, 2014 updateCenters for Disease Control and Prevention, Atlanta, Georgia; USA. 2014.

8. Abiodun OM, Balogun OR. Sexual activity and contraceptive use among young female students of tertiary educational institutions in Ilorin, Nigeria. Contraception 2009;79:146-9.

9. Umoh AV, Abah MG. Contraception awareness and practice among antenatal attendees in Uyo, Nigeria. Pan Afr Med J $2011 ; 10: 53$.

10. Undelikwo VA, Osonwa OK, Ushie MA, Osonwa RH. Family planning behaviours and decision-making among couples in Cross River State, Nigeria. Int J Learn Dev 2013;3:2164-4063.

11. Ushie MA, Otu JE, Undelikwo VA. A comparative analysis of fertility differentials in Cross River State. Dev Country Stud 2014;4:36-40.

12. Cross River State GovernmentStrategic Health Development Plan (2010-2015). Calabar, NigeriaCross River State Ministry of Health.

13. NPC and ORC Macro 2004. Nigeria Demographic and Health Survey 2003. Calverton, MarylandNational Population Commission and ORC Macro.

14. Oyedokun AO. Determinants of contraceptive usage: Lessons from women in Osun State of Nigeria. J Human Soc Sci 2007;1:1-14.

15. Nyauchi B, Omedi G. Determinants of unmet need for family planning among women in rural Kenya. Afr Pop Stud Suppl 2014;2:999-1008.

16. Eliason S, Baiden F, Quansah-Asare G, Graham-Hayfron Y, Bonsu D, Phillips J, et al. Factors influencing the intention of women in rural Ghana to adopt postpartum family planning. Reprod Health 2013;34:1-8.
17. Gaur DR, Kumar GM, Meenu G. Contraceptive practices and related factors among females in predominantly rural Muslim area of North India. Internet $\mathrm{J}$ World Health Soc Politics 2008;5:1.

18. Juma PA, Mutombo N, Mukiira C. Women's attitudes towards receiving family planning services from community health workers in rural Western Kenya. Afr Health Sci 2015;1:161-70.

19. WHO. Family planning/contraception. [cited 2015 March 11] Available from: http:/www.who.int/mediacentre/factsheets/fs351/ en/. World Health Organization: Geneva, Switzerland.

20. Ochako R, Mbondo M, Aloo S, Kaimenyi S, Thompson R, Temmerman $\mathrm{M}$, et al. Barriers to modern contraceptive methods uptake among young women in Kenya: A qualitative study. BMC Public Health 2015;15:118.

21. Steinfeld RL, Newmann SJ, Onono M, Cohen CR, Bukusi EA, Grossman D. Overcoming barriers to family planning through integration: Perspectives of HIV-positive men in Nyanza Province, Kenya. AIDS Res Treat 2013;2013:1-8.

22. WHO Infertility definition and terminology. Available from: http://www.who.int/reproductivehealth/topics/infertility/ definitions/en/. World Health Organization: Geneva, Switzerland. [Last accessed 2015 Feb 18].

23. Olugbenga-Bello AI, Abodunrin OL, Adeomi AA. Contraceptive practices among women in rural communities in South-Western Nigeria. Global J Med Res 2011;11:1-7.

24. Utoo BT, Swende TZ, Utoo PM, Ifenne DI. Barriers to utilization of modern methods of family planning amongst women in a community in South-South of Nigeria. Trop J Obstet Gynaecol 2012;29:66-70.

25. Ngwu CN. Awareness and attitude of family planning among rural women of Nsukka Local Government Area: Implications for social work intervention. Mediterranean J Soc Sci 2014;5:1404-10.

26. Ibrahim G, Rabiu A, Abubakar IS. Knowledge, attitude and practice of contraceptives among grand multiparous women attending antenatal clinic in a specialist hospital, Kano, Nigeria. Niger J Basic Clin Sci 2015;12:90-4.

27. Isonguyo IN, Adindu A. Adolescents and utilization of family planning services in rural community of Nigeria. Res Human Soc Sci 2013;3:1-12.

28. Omideyi AK, Akinyemi AI, Aina OI, Adeyemi AB, Fadeyibi $\mathrm{OA}$, Bamiwuye $\mathrm{SO}$, et al. Contraceptive practice, unwanted pregnancies and induced abortion in Southwest Nigeria. Global Public Health 2011;6(Suppl):1S52-72.

29. Izugbara C, Ibisomi L, Ezeh AC, Mandara M. Gendered interests and poor spousal contraceptive communication in Islamic northern Nigeria. J Fam Plan Reprod Health Care 2010;36: 219-24.

30. Izugbara $\mathrm{CO}$, Ezeh AC. Women and high fertility in Islamic Northern Nigeria. Stud Fam Plan 2010;41:193-204.

31. Ijadunola MY, Abiona TC, Ijadunola KT, Afolabi OT, Esimai OA, Olaolorun FM. Male involvement in family planning decision making in Ile-Ife, Osun State, Nigeria. Afr J Reprod Health 2010;14:43-50.

32. Adelekan A, Omoregie $\mathrm{P}$, Edoni E. Male involvement in family planning: Challenges and way forward. Int J Pop Res 2014;2014:1-9. 